\title{
Peningkatan Kemampuan Membaca Puisi Anak dengan Pendekatan Contextual Teaching and Learning (CTL) pada Siswa Kelas V Sekolah Dasar
}

\author{
Sutarti* \\ SD Negeri 2 Nanggulan Kecamatan Cawas Kabupaten Klaten \\ *sutarti@gmail.com
}

\begin{abstract}
This study aims to determine the improvement of children's poetry reading skills with the Contextual Teaching and Learning approach in Class V Students of SDN 2 Nanggulan, District of Cawas, Klaten Regency, Semester I, Academic Year 2018/2019. This Classroom Action Research was conducted in the fifth grade of Nanggulan Elementary School 2 in Cawas District, Klaten Regency with a total of 17 students, consisting of 3 male students and 14 female students. This classroom action research is carried out three cycles in a continuous manner. Each cycle is carried out by planning, implementing, observing, and reflecting to determine the effectiveness of the action. Based on the analysis, it can be concluded as follows: First, based on observations of teacher performance the results of the average score of teacher performance have increased from learning Cycle I for 1.3 Cycle II learning to 2.3, and at Cycle III 2.7. With the criteria of a sufficient limit score is a score of 2 and a score of 3 is good; Second, based on student activity data for three cycles, the average score about student activity experienced an increase from Cycle I learning at 1.2 learning Cycle II to 2.0 and in Cycle III learning to 2.8; Third, based on the results of the assessment of reading children's poetry with the Contextual Teaching and Learning approach, the average score of the test results and assignments has increased from Cycle I learning to 70.89 Cycle II learning to 75.59 and Cycle III learning to 79.71 . Increasing the percentage of classical learning completeness by learning cycle I was $41.18 \%$, learning Cycle II became $58.82 \%$, and learning in Cycle III reached $82.35 \%$. Thus through the Contextual Teaching and Learning approach the ability to read children's poetry in Class V students of SD Negeri 2 Nanggulan, District of Cawas, Klaten Regency, in the first semester of school year 2018/2019 can increase.
\end{abstract}

\begin{abstract}
Abstrak: Penelitian ini bertujuan untuk mengetahui peningkatan kemampuan membaca puisi anak dengan pendekatan Contextual Teaching and Learning pada Siswa Kelas V SD Negeri 2 Nanggulan Kecamatan Cawas Kabupaten Klaten Semester I Tahun Pelajaran 2018/2019. Penelitian Tindakan Kelas ini dilaksanakan di kelas V SD Negeri 2 Nanggulan Kecamatan Cawas Kabupaten Klaten dengan jumlah siswa sebanyak 17 siswa, terdiri dari 3 siswa laki laki dan 14 siwa perempuan. Penelitian tindakan kelas ini dilakukan tiga siklus secara berkelanjutan. Setiap siklus dilakukan perencanaan, pelaksanaan, pengamatan, dan refleksi untuk mengetahui efektifitas tindakan. Berdasarkan analisis dapat disimpulkan sebagai berikut: Pertama, berdasarkan pengamatan terhadap kinerja guru diperoleh hasil skor rata-rata kinerja guru mengalami peningkatan dari pembelajaran Siklus I sebesar 1,3 pembelajaran Siklus II menjadi 2,3, dan pada pembelajaran Siklus III 2,7. Dengan kriteria skor batas cukup adalah skor 2 dan skor 3 adalah baik; Kedua, berdasarkan data aktivitas siswa selama tiga siklus, skor rata-rata tentang aktivitas siswa mengalami peningkatan dari pembelajaran Siklus I sebesar 1,2 pembelajaran Siklus II menjadi 2,0 dan pada pembelajaran Siklus III menjadi 2,8; Ketiga, berdasarkan hasil penilaian membaca puisi anak dengan pendekatan Contextual Teaching and Learning, diperoleh rata-rata nilai hasil tes dan tugas mengalami peningkatan dari pembelajaran Siklus I sebesar 70,89 pembelajaran Siklus II menjadi 75,59 dan pada pembelajaran Siklus III menjadi 79,71. Peningkatan prosentase ketuntasan belajar klasikal sebesar pembelajaran siklus I sebesar 41,18 \%, pembelajaran Siklus II menjadi 58,82 \%, dan pada pembelajaran Siklus III mencapai $82,35 \%$. Dengan demikian melalui pendekatan Contextual Teaching and Learning kemampuan membaca puisi anak pada Siswa Kelas V SD
\end{abstract}


Negeri 2 Nanggulan Kecamatan Cawas Kabupaten Klaten semester I tahun pelajaran 2018/2019 dapat meningkat

Kata Kunci: membaca puisi anak, contextual teaching and learning.

\section{Pendahuluan}

Bahasa memiliki peran sentral dalam perkembangan intelektual, sosial, dan emosional peserta didik dan merupakan penunjang keberhasilan dalam mempelajari semua bidang studi. Pembelajaran bahasa diharapkan membantu peserta didik mengenal dirinya, budayanya, dan budaya orang lain, mengemukakan gagasan dan perasaan, berpartisipasi dalam masyarakat yang menggunakan bahasa tersebut, dan menemukan serta menggunakan kemampuan analitis dan imaginatif yang ada dalam dirinya.

Dinamika proses pembelajaran bahasa Indonesia yang di dalamnya mencakup berbagai aspek harus diikuti oleh para pendidik. Pembelajaran Bahasa Indonesia yang mencakup aspek mendengarkan, berbicara, membaca, dan menulis mempunyai porsi yang seimbang dalam pelaksanaannya. Dari keempat aspek tersebut keterpaduan harus terjadi pada ruang lingkup pelajaran Bahasa Indonesia.

Pembelajaran bahasa Indonesia diarahkan untuk meningkatkan kemampuan peserta didik untuk berkomunikasi dalam bahasa Indonesia dengan baik dan benar baik secara lisan maupun tulis, serta menumbuhkan apresiasi terhadap hasil karya kesusastraan manusia Indonesia [1]. Dengan demikian, tujuan pembelajaran bahasa Indonesia dalam komponen bersastra mengutamakan pembinaan kegiatan mengapresiasi sastra. Apresiasi sastra adalah kegiatan menghayati cipta sastra dengan sungguh-sungguh sehingga tumbuh pengertian, penghargaan, kepekaan pikiran kritis, dan kepekaan perasaan yang baik terhadap cipta sasta. Mengajarkan bahasa Indonesia di Sekolah Dasar pada hakekatnya adalah mengembangkan potensi berbahasa siswa sesuai dengan fungsi bahasa sebagai wahana komunikasi untuk mengembangkan potensi intelektual, emosional, sosial, dan mengembang-kan sikap positif terhadap bahasa Indonesia.

Pembelajaran bahasa diarahkan pada upaya mempertajam kepekaan perasaan siswa, kepekaan sosial. Ditegaskan oleh Imam Syafi'ie (1996:19) bahwa mempertajam kepekaan sosial ini akan memperkaya strategi komunikasi [2]. Siswa tidak hanya diharapkan mampu memahami informasi yang disampaikan secara lugas atau secara langsung, melainkan juga yang disampaikan secara terselubung atau tidak langsung. Mengingat pentingnya pembelajaran bahasa Indonesia di Sekolah Dasar yang merupakan dasar untuk mengembangkan pengetahuan keterampilan berbahasa, dan sikap positif terhadap bahasa Indonesia, maka seorang guru hendaknya betul-betul dapat membawa anak ke arah berbahasa yang komunikatif. Karena melalui bahasa manusia dapat saling berhubungan (berkomunikasi), saling berbagi pengalaman, saling belajar dari yang lain, dan meningkatkan kemampuan intelektual [3].

Tercapainya pembelajaran bahasa Indonesia di sekolah dasar juga dipengaruhi oleh guru. Agar dapat melaksanakan pembelajaran bahasa dengan baik, guru dituntut untuk memahami kurikulum. Guru juga harus mampu memilih, mengembangkan, dan menguasai bahan ajar yang relevan dan secara kreatif mengembangkan strategi pembelajaran untuk menumbuhkan nilai, sikap, serta kemampuan. Selain itu guru juga dituntut mampu menyusun dan menggunakan alat evaluasi yang diperlukan. Keistimewaan dalam Kurikulum 2013 adalah menempatkan bahasa sebagai penghela ilmu pengetahuan. Oleh karena itu, pembelajaran bahasa Indonesia dalam Kurikulum 2013 diorientasikan pada pembelajaran berbasis teks, jadi pembelajaran bahasa mempertimbang-kan konteks situasi pemakaian bahasa itu sendiri. Pembelajaran berbasis teks akan memberikan wawasan kepada siswa tentang berbagai teks, salah satunya teks sastra (teks cerpen, teks novel, teks puisi, dan teks drama). Dalam hal ini pembelajaran sastra Indonesia untuk Sekolah Menengah Pertama khususnya membaca puisi yang merupakan bagian dari mata pelajaran bahasa Indonesia dalam hal apresiasi sastra harus diperhatikan. Peletakan dasar-dasar berapresiasi dan berekspresi 
melalui kegiatan melisankan hasil sastra merupakan kompetensi dasar bersastra pada anak yang harusnya mendapatkan porsi lebih dalam pembelajaran.

Kegiatan membaca sebenarnya merupakan suatu bentuk keterampilan yang cukup kompleks dan rumit. Artinya, proses kegiatan membaca melibatkan suatu bagian-bagian yang sering disebut sebagai keterampilan yang lebih kecil. Keterampilan tersebut antara lain: pengenalan terhadap aksara serta tanda-tanda baca, menghubungkan aksara serta tanda-tanda baca dengan unsur linguistik yang formal, menghubungkan aksara dan unsur-unsur linguistik dengan makna [4]. Pembelajaran sastra pada siswa akan memberikan manfaat dan pemahaman yang luas tentang berbagai bentuk karya sastra dan nilai-nilai yang terkandung dalam karya sastra tersebut. Pembelajaran sastra dapat membantu proses memahami sastra secara utuh apabila cakupannya meliputi empat manfaat, yaitu: membantu keterampilan berbahasa, meningkatkan pengetahuan budaya, mengembangkan cipta dan rasa dan menunjang pembentukan watak.

Kegiatan membaca puisi yang membacanya tidak disamakan dengan yang lain merupakan pembelajaran yang mempunyai nilai seni, yang di dalamnya terdapat unsur keindahan bahasa, penghayatan yang dimanifestasikan dengan gerak mimik dan pantomimik. Bahasa yang indah merupakan ungkapan penyair yang diambil dari sumber imajinatif maupun sumber kejadian di alam sekitar mengajak para pembaca untuk berapresiasi. Para pembaca diajak tanggap terhadap kejadian yang ada dalam bacaan. Menurut Waluyo, (2008:1) Puisi adalah karya sastra dengan bahasa yang dipadatkan, dipersingkat, dan diberi irama dengan bunyi yang padu dan pemilihan kata-kata yang khas[5]. Ciri-ciri kebahasaan puisi meliputi pemadaan bahasa, pemilihan kata khas (makna kias, lambang, rima), kata konkret, pengimajian, irama, tata wajah. Bentuk karya sastra yang mengungkapkan pikiran dan perasaan penyair secara imajinatif dan disusun dengan mengkoordinasikan semua kekuatan bahasa dengan pengkonsentrasian struktur fisik dan struktur batinnya. Sehingga bisa menyatu antara fisik dan batin.

Puisi adalah sebuah sastra yang sangat memperlihatkan aspek kebahasaan, sehingga bahasa dalam puisi adalah bahasa yang tersaing. Pemilihan kata diseleksi dengan ketat, dipertimbangkan dari berbagai sisi baik yang menyangkut unsur bunyi, bentuk, dan makna yang kesemuanya harus memenuhi persyaratan untuk memperoleh efek keindahan. Puisi biasa didefinisikan sebagai karangan yang terikat. Bahasa dipadatkan agar berkekuatan gaib. Kata-kata dan kalimat dalam larik-larik puisi lebih bermakna luas dari pada alenia-alenia pada sebuah prosa hal yang mengikat puisi adalah banyaknya baris dalam setiap bait, banyak kata-kata dalam tiap baris, banyak suku kata dalam tiap baris, rima, dan irama.

Menurut Waluyo, (2008:1) puisi adalah karya sastra dengan bahasa yang dipadatkan, dipersingkat, dan diberi irama dengan bunyi yang padu dan pemilihan kata-kata yang khas [5]. Ciriciri kebahasaan puisi meliputi pemadatan bahasa, pemilihan kata khas (makna kias, lambang, rima), kata konkret, pengimajian, irama, tata wajah dengan membaca dan mendengarkan puisi, siswa mendapatkan pemahaman dan dapat menghargai puisi sebagai karya seni. Kata yang dipilih dalam puisi dipertimbangkan betul dari berbagai efek dan aspek pengucapannya. Puisi adalah genre sastra yang banyak menggunakan makna kias. Penggunaan lambang dalam puisi sering kita jumpai, lakilaki gagah dan tampan dilambangkan dengan burung dara jantan, misalnya persamaan bunyi yang harmonis dan berulang menciptakan konsentrasi dan kekuatan bahasa. Penyair ingin menggambarkan sesuatu secara lebih konkret, maka kata-kata yang dipilih diperkonkret, misal kaki kuda yang bersepatu disebut sebagai kuku besi. Pengimajian adalah kata atau susunan kata-kata yang dapat memperjelas atau memperkonkret apa yang dinyatakan oleh penyair. Melalui pengimajian seolah-olah apa yang digambarkan oleh penyair dapat dilihat, didengar dan dirasa.

Irama dalam puisi merupakan pengulangan yang teratur, dalam suatu baris puisi menimbulkan gelombang yang menimbulkan keindahan. Berarti pula pergantian keras-lembut, tinggi-rendah, panjang-pendek kata secara berulang-ulang dengan tujuan menciptakan gelombang yang memperindah puisi. Tata wajah puisi ada yang konvensional ada yang tidak konvensional, bahkan ada yang dibentuk menyerupai gambar tertentu.

Teknik latih adalah suatu pengetahuan dan kepandaian dalam membuat perencanaan untuk dilatihkan kepada siswa agar mudah diterima dan dilakukan sehingga bermanfaat [6]. Seni baca puisi menurut Fuad Hassan(1988:152), kata seni adalah ungkapan yang memuat anasir estetik atau 
keindahan [7]. Sedangkan baca, jika mendapat awalan me menjadi membaca, berarti melisankan tulisan atau menyuarakan wacana tertulis yang berbentuk puisi. Adapun puisi adalah kalimatkalimat yang tertulis pada seluruh naskah dipadukan, sehingga terangkum makna yang terkandung dalam sebuah puisi. Puisi atau verse berasal dari bahasa latin versus yang berasal dari kata kerja verso, versare, yang berarti to turn (menghadap). Dalam bahasa Inggris verse mengacu pada pengaturan baris demi baris yang disengaja yang membedakannya dari prosa [8].

Berdasarkan batasan yang telah disebutkan di atas maka seni baca puisi adalah suatu ungkapan aspek keindahan yang mengandung kalimat-kalimat tertulis yang padu dan disuarakan/dilisankan di depan penonton, sehingga melalui kegiatan tersebut pembaca bermaksud mengajak pendengar/penonton memahami dan merasa apa yang dibacanya. Dengan demikian isi atau pesan yang ada dalam puisi dapat diterima oleh pendengar.

Terdapat beberapa problematika dalam pengajaran sastra yang harus segera diatasi oleh guru bahasa di sekolah. Harus segera diatasi karena problematika pengajaran sastra menyebabkan kurang optimalnya pengajaran sastra di sekolah. Salah satu permasalahan yang harus dihadapi adalah kita menginginkan siswa di lapangan dapat mengapresiasi, menganalisis dan juga dapat memproduksi karya sastra sebagai outcome dalam pengajaran sastra di sekolah. Selama ini pengajaran sastra di sebagian besar sekolah termasuk di SMP Pangudi Luhur Gantiwarno hanya terjadi dalam ruang yang diapit oleh dinding kelas. Hasilnya, daya imajinasi dan kreasi siswa kurang berkembang optimal. Misalnya ketika siswa mendapat tugas membuat puisi berkenaan dengan alam. Namun guru yang bersangkutan tidak mengajak mereka ke alam terbuka. Padahal di ruang tertutup dinding kelas, kurang mendukung dalam menumbuh-kembangkan daya imajinasi dan kreasi mereka dalam proses penciptaan puisi. Seharusnya, guru mengajak siswa keluar, ke alam terbuka dan membantu mereka dalam proses penciptaan karya sastra.

Skill atau keterampilan guru dalam menyampaikan materi membaca puisi sangat dibutuhkan. Metode demonstrasi dan model dari guru sangat dominan, agar para siswa dapat melihat, mendengarkan, dan menghayati, kemudian berekspresi sendiri. Pembelajaran sastra khususnya membaca puisi dalam penyampaiannya tidak hanya ceramah, namun berdemonstrasi timbal balik antara guru kemudian siswa sangat diperlukan. Contextual Teaching and Learning (CTL) merupakan salah satu konsep belajar yang membantu guru mengaitkan antara materi yang diajarkan dengan situasi dunia nyata siswa yang mendorong siswa mengaitkan antara pengetahuan yang dimilikinya dengan penerapannya dalam kehidupan mereka sehari-hari. Pengetahuan dan keterampilan siswa diperoleh dari usaha siswa mengkonstruksi sendiri pengetahuan dan keterampilan ketika ia belajar [9].

Pada hakekatnya, pendekatan kontekstual merupakan respon terhadap pendekatan yang pernah sangat populer yaitu behaviorism yang menekankan konsep stimulus dengan pelatihan yang bersifat drill. Untuk dapat berbahasa secara wajar seperti dalam kehidupan nyata dengan situasi yang sangat beragam diperlukan "critical thinking" dan pembelajaran bermakna. Bila siswa memahami adanya hubungan antara apa yang diperoleh di kelas atau sekolah dengan kehidupan mereka di luar, maka mereka akan menyadari manfaat belajar. Selain itu mereka akan menyadari bahwa belajar itu penting, sehingga mereka memanfaatkan waktu dengan sebaik-baiknya.

Pendekatan CTL memiliki tujuh komponen utama, yaitu konstruktivisme (contructivism), menemukan (inquiry), bertanya (questioning), masyarakat belajar (learning community), permodelan (modeling) refleksi (reflection) dan penilaian yang sebenarnya (authentic assessment). Pendekatan kontekstual dalam kelas bahasa merupakan pendekatan yang memungkinkan siswa untuk menguatkan, memperluas dan menerapkan pengetahuan dan keterampilan berbahasa mereka dalam berbagai tatanan, baik di sekolah dan di luar sekolah. Siswa belajar untuk memecahkan masalah yang mereka hadapi dengan berbahasa aktif, misalnya dalam bentuk simulasi atau diskusi. Bila pendekatan kontekstual diterapkan dengan benar, siswa terlatih untuk menghubungkan apa yang diperoleh di kelas dengan kehidupan nyata. Untuk ini guru perlu benar-benar memahami pendekatan kontekstual lebih dahulu kemudian menerapkannya dengan benar sehingga siswa dapat belajar secara efektif. Guru perlu mendapat latihan atau inservice training tentang kontekstual bagaimana mengajar bahasa menggunakan berbagai strategi dengan prinsip-prinsip kontekstual, sehingga siswa dapat menggunakan bahasa dalam kehidupan sehari-hari dengan benar. 
Pendekatan CTL (Contextual Teaching and Learning ) sangat tepat untuk dilaksanakan dalam pembelajaran membaca puisi. Guru dalam proses pembelajaran harus melaksanakan prinsip dasar pembelajaran Contextual Teaching and Learning (CTL) yang di dalamnya berisi antara lain (1) Menekankan pada pemecahan masalah, (2) Mengenal kegiatan mengajar yang terjadi di berbagai konteks, seperti di rumah, masyarakat, dan tempat kerja, (3) Mengajar siswa untuk memantau dan mengarahkan belajarnya sehingga menjadi pembelajar yang aktif dan terkendali, (4) Menekankan pembelajaran dalam konteks kehidupan siswa, (5) Mendorong siswa belajar dari satu dengan lainnya dan belajar bersama, dan (6) Menggunakan penilaian otentik.

Kelemahan-kelemahan penyajian pembelajaran membaca puisi di sekolah perlu disikapi untuk disempurnakan. Guru perlu strategi agar dalam penyampaian pembelajaran mendapat hasil yang maksimal. Kepiawian guru dalam melatih, teknik latih, kontinuitas latihan, kejelian melihat kondisi siswa, serta kecermatan mensikapi sangat menentukan untuk mencapai keberhasilan. Di samping hal tersebut, minat membaca puisi yang sangat rendah masih menjadi masalah utama dalam pembelajaran. Hal ini menjadi salah satu masalah yang muncul di SD Negeri 2 Nanggulan Cawas Klaten terutama di kelas V. Dari hasil tes membaca puisi anak, lebih dari separo siswa belum mencapai Kriteria Ketuntasan Minimal (KKM) yang ditentukan oleh sekolah yaitu sebesar 75 . Salah satu penyebabnya adalah anggapan siswa bahwa membaca puisi merupakan suatu keterampilan berbahasa yang kurang menarik dan kurang bermanfaat. Akibatnya kualitas hasil belajar membaca puisi para siswa sampai saat ini belum memuaskan $(70 \%$ siswa masih belum tuntas belajar). Oleh karenanya kelemahan-kelemahan penyajian pembelajaran membaca puisi di sekolah perlu disikapi untuk disempurnakan. Guru perlu strategi agar dalam penyampaian pembelajaran mendapat hasil yang maksimal. Kepiawaian guru dalam melatih, teknik latih, kontinuitas latihan, kejelian melihat kondisi siswa, serta kecermatan menyikapi sangat menentukan untuk mencapai keberhasilan.

Berdasarkan latar belakang yang telah disampaikan di atas, rumusan masalah dalam penelitian ini adalah Apakah kemampuan membaca puisi anak pada siswa kelas V SD Negeri 2 Nanggulan Kecamatan Cawas Kabupaten Klaten Semester I Tahun Pelajaran 2018/2019 dapat ditingkatkan dengan pendekatan Contextual Teaching and Learning? Berdasarkan rumusan tersebut maka tujuan dari penelitian ini adalah untuk mengetahui peningkatan kemampuan membaca puisi anak dengan pendekatan Contextual Teaching and Learning pada Siswa Kelas V SD Negeri 2 Nanggulan Kecamatan Cawas Kabupaten Klaten Semester I Tahun Pelajaran 2018/2019.

\section{Metode Penelitian}

Penelitian ini dilaksanakan di kelas V SD Negeri 2 Nanggulan Kecamatan Cawas Kabupaten Klaten Semester I Tahun Pelajaran 2018/2019. Waktu penelitian dilakukan pada jam tatap muka kegiatan pembelajaran awal hingga pertengahan semester ganjil tahun pelajaran 2018/2019 yaitu bulan Agustus 2018 sampai awal bulan Oktober 2018.

Penelitian ini menggunakan desain penelitian tindakan kelas dengan menggunakan tiga siklus. Tiap siklus terbagi atas empat tahap, yaitu perencanaan, tindakan, observasi dan refleksi. Pada siklus pertama guru memberikan teks puisi untuk dibaca dalam hati secara berulang-ulang, kemudian siswa diminta untuk membaca nyaring sesuai kemampuannya, dan dianalisis hasilnya. Selanjutnya diberikan tindakan berupa teknik membaca puisi yang baik, kemudian meminta siswa untuk membaca puisi. Langkah berikutnya diadakan analisis hasil membaca siswa, berarti siklus I selesai. Berdasarkan hasil siklus I, diadakan langkah-langkah yang sama dengan memperhatikan aspek aspek yang belum tercapai yang harus dilakukan tindakan berikutnya pada siklus II dan Siklus III.

Data dalam Penelitian Tindakan Kelas ini berupa data yang berkaitan dengan proses pembelajaran membaca puisi dengan pendekatan Contectual Teaching and Learning (CTL) di kelas V Sekolah Dasar Negeri 2 Nanggulan Cawas Klaten. Dalam hal ini data utamanya adalah silabus, materi ajar, Rencana Pelaksanaan Pembelajaran (RPP), alat tes, hasil penilaian baca puisi.

Teknik pengumpulan data menggunakan observasi, wawancaa dan tes.Data yang dipergunakan untuk dianalisis terdiri dari data primer dan sekunder. Data primer bersumber dari wawancara dengan guru dan siswa. Sedangkan data sekunder bersumber dari daftar nilai membaca 
puisi, skor kinerja guru, dan skor kinerja siswa. Semua data yang ada, baik data primer maupun sekunder diolah dengan mencari rata-rata setiap nilai test kemudian dijumlah dan dicari rata-rata keseluruhan selanjutnya hasilnya disesuaikan dengan indikator belajar tuntas yang diharapkan dalam bentuk persentase.

Tolok ukur keberhasilan penelitian ini adalah sebagai berikut :

1. meningkatnya kinerja guru dalam pembelajaran membaca puisi dengan menggunakan pendekatan Contekstual Teaching and Learning(CTL).

2. meningkatnya aktivitas belajar siswa kelas $\mathrm{V}$ pada pembelajaran membaca puisi dengan menggunakan pendekatan Contekstual Teaching and Learning(CTL)

3. meningkatnya hasil belajar siswa kelas $\mathrm{V}$ pada pembelajaran membaca puisi dengan menggunakan pendekatan Contekstual Teaching and Learning(CTL). Nilai rata-rata komulatif minimal 75, tingkat ketuntasan mencapai $80 \%$..

\section{Hasil dan Pembahasan}

\section{Pra Tindakan}

Berdasarkan hasil wawancara dengan guru kelas $\mathrm{V}$ dan pengamatan terhadap data hasil belajar siswa pada materi Baca Puisi, diketahui bahwa hasil belajar Baca Puisi masih rendah. Kriteria Ketuntasan Minimal yang ditentukan sekolah adalah 75, akan tetapi sebagian besar siswa kelas V belum mencapai KKM yang ditentukan. Berdasarkan data dalam daftar nilai dan informasi dari guru kelas, dari 17 anak yang mencapai batas tuntas baru 5 anak atau 29,41\% dan yang belum tuntas mencapai 12 anak atau $70,59 \%$.

Berdasarkan analisa terhadap data dan keterangan guru kelas $\mathrm{V}$, hal ini disebabkan karena proses pembelajaran puisi yang masih konvensional, ketika memberikan pembelajaran, guru hanya menentukan sebuah puisi, kemudian dibacakan di depan kelas, anak disuruh memperhatikan, kemudian anak disuruh mencoba membaca puisi di depan kelas. Aspek seni baca puisi yang menyangkut vokal, penghayatan, dan penampilan tidak mendapatkan perhatian khusus. Dalam berlatih vokal, kejelasan ucapan, jeda, dan intonasi tidak mendapatkan latihan secara khusus. Isi puisi juga tidak mendapatkan penjelasan dan kupasan sehingga peghayatan dan ekspresi tidak muncul dalam diri siswa ketika membacakan puisi. Aspek penampilan seperti gerakan, pandangan mata dan pengelolaan diri tidak mendapatkan perhatian.

\section{Hasil Penelitian dan Pembahasan}

1. Data Kinerja Guru

Tabel 1 Rekapitulasi Hasil Pengamatan Kinerja Guru Tiga Siklus

\begin{tabular}{lcccc}
\hline No & $\begin{array}{c}\text { Item Observasi } \\
\text { Kinerja Guru }\end{array}$ & Siklus I & Siklus II & Siklus III \\
\hline 1 & A & 1 & 2 & 3 \\
2 & B & 1 & 2 & 3 \\
3 & C & 3 & 3 & 3 \\
4 & D & 1 & 2 & 2 \\
5 & E & 1 & 2 & 2 \\
6 & F & 1 & 3 & 3 \\
Jumlah Skor & & 8 & 14 & 16 \\
Skor rata-rata & & 1,3 & 2,3 & 2,7 \\
\hline
\end{tabular}


Ket :

$\mathrm{A}=$ Kemampuan guru mempersiapkan kondisi psikologis anak dalam pembelajaran.

$\mathrm{B}=$ Kemampuan guru dalam menyampaikan materi membaca puisi

$\mathrm{C}=$ Kemampuan guru dalam memberi bimbingan siswa dalam melakukan baca puisi.

$\mathrm{D}=$ Kemampuan guru dalam memotivasi dan menarik minat siswa untuk bertanya.

$\mathrm{E}=$ Kemampuan guru dalam mengelola kelas

$\mathrm{F}=$ Kemampuan guru dalam mengorganisasikan waktu dengan efisien.

Berdasarkan data di atas, skor rata-rata kinerja guru mengalami peningkatan dari pembelajaran Siklus I sebesar 1,3 pembelajaran Siklus II menjadi 2,3, dan pada pembelajaran Siklus III 2,7.

Berdasarkan pengamatan dan refleksi, ini terjadi karena :

a. Pada pembelajaran Siklus I, kemampuan guru menyiapkan suasana psikologis siswa kurang, terbukti banyak anak gaduh; kemampuan menyampaikan materi masih kurang.

b. Pada Pembelajaran Siklus II, guru mulai mampu menyiapkan kondisi psikologis siswa, mampu memotivasi siswa, namun masih ada kelemahan pengelolaan kelas ternyata belum baik karena banyak anak yang dari kelas lain sering mengganggu anak yang sedang mengikuti pembelajaran.

c. Pada Pembelajaran Siklus III, keterbukaan dan komunikasi lebih intensif, guru mampu menyiapkan kondisi psikologis anak, tidak ada anak dari kelas lain mengganggu, materi baca puisi dapat dilakukan dengan baik mulai dari penghayatan, olah vocal, dan penampilan, waktu lebih efektif.

2. Data Aktivitas Siswa

Berdasarkan pengamatan siswa selama tiga siklus diperoleh data sebagai berikut:

Tabel 2 Skor Aktivitas Siswa Tiga Siklus

\begin{tabular}{ccccc}
\hline No & Item Observasi & Siklus I & Siklus II & Siklus III \\
\hline 1 & A & 2 & 1 & 3 \\
2 & B & 1 & 2 & 2 \\
3 & C & 1 & 3 & 3 \\
4 & D & 1 & 2 & 3 \\
5 & E & 1 & 2 & 3 \\
6 & F & 1 & 2 & 3 \\
& Jmlah Skor & 7 & 12 & 17 \\
& Skor rata-rata & 1,2 & 2,0 & 2,8 \\
\hline
\end{tabular}




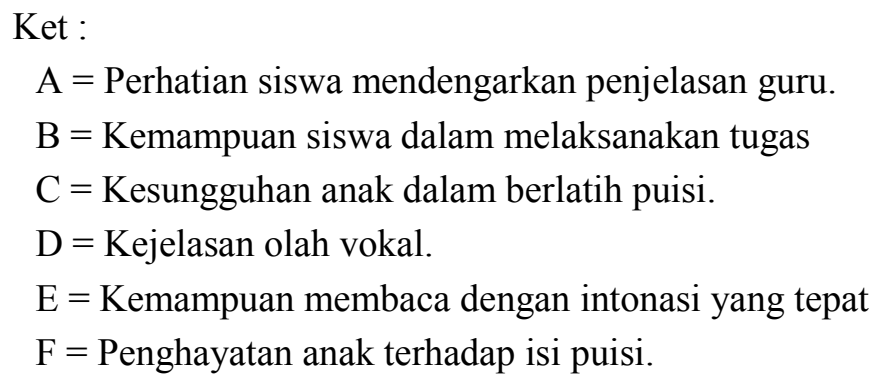

Berdasarkan data aktivitas siswa selama tiga siklus, skor rata-rata tentang aktivitas siswa mengalami peningkatan dari pembelajaran Siklus I sebesar 1,2 pembelajaran Siklus II menjadi 2,0 dan pada pembelajaran Siklus III menjadi 2,8.

Berdasarkan pengamatan dan refleksi, ini terjadi karena :

a. Pada pembelajaran Siklus I, aktivitas siswa kurang baik, banyak anak gaduh; anak malu bertanya dan malu menjawab pertanyaan, kerjasama dan kesungguhan dalam berdiskusi kurang.

b. Pada Pembelajaran Siklus II, kondisi psikologis siswa sudah mulai siap, kemauan untuk bertanya dan menjawab pertanyaan lebih baik, namun masih banyak anak dari kelas lain yang mengganggu.

c. Pada Pembelajaran Siklus III, anak terlepas dari beban psikologis, olah vokal, penghayatan, dan penampilan dalam pembelajaran baca puisi sudah bagus.

3. Hasil Tes Formatif dan Ketuntasan Belajar

Tabel 3 Rekapitulasi Hasil Penilaian Membaca Puisi Anak Tiga Siklus

\begin{tabular}{ccccc}
\hline Siklus & $\begin{array}{c}\text { Rata- } \\
\text { Rata }\end{array}$ & $\begin{array}{c}\text { Nilai } \\
\text { Tertinggi }\end{array}$ & $\begin{array}{c}\text { Nilai } \\
\text { Terendah }\end{array}$ & $\begin{array}{c}\text { Tingkat } \\
\text { Ketuntasan }\end{array}$ \\
\hline I & 70,89 & 85 & 60 & $41,18 \%$ \\
II & 75,59 & 85 & 65 & $58,82 \%$ \\
III & 79,71 & 85 & 65 & $82,35 \%$ \\
\hline
\end{tabular}

Rata-rata nilai hasil tes dan tugas mengalami peningkatan dari pembelajaran Siklus I sebesar 70,89 pembelajaran Siklus II menjadi 75,59 dan pada pembelajaran Siklus III menjadi 79,71. Peningkatan prosentase ketuntasan belajar klasikal sebesar pembelajaran siklus I sebesar 41,18 \%, pembelajaran Siklus II menjadi 58,82 \%, dan pada pembelajaran Siklus III mencapai $82,35 \%$.

Berdasarkan hasil pembelajaran siklus I, pembelajaran siklus II, dan pembelajaran Siklus III, ternyata melakukan pembelajaran membaca di luar kelas dengan pentahapan hasil pembelajaran lebih baik. Dengan demikian hipotesis yang berbunyi "Dengan pendekatan Contextual Teaching and Learning kemampuan membaca puisi anak pada Siswa Kelas V SD 2 Nanggulan Kecamatan Cawas Kabupaten Klaten dapat meningkat" dapat terbukti kebenarannya.

\section{Kesimpulan}

Berdasarkan hasil analisis dari tindakan berkaitan dengan peningkatan kemampuan membaca puisi anak dengan pendekatan contextual teaching and learning (CTL) pada siswa kelas V SD Negeri 2 Nanggulan Cawas Klaten dapat ditarik kesimpulan sebagai berikut. 
Pertama, berdasarkan pengamatan terhadap kinerja guru diperoleh hasil skor rata-rata kinerja guru mengalami peningkatan dari pembelajaran Siklus I sebesar 1,3 pembelajaran Siklus II menjadi 2,3, dan pada pembelajaran Siklus III 2,7. Dengan ktiteria skor batas cukup adalah skor 2 dan skor 3 adalah baik.

Kedua, berdasarkan data aktivitas siswa selama tiga siklus, skor rata-rata tentang aktivitas siswa mengalami peningkatan dari pembelajaran Siklus I sebesar 1,2 pembelajaran Siklus II menjadi 2,0 dan pada pembelajaran Siklus III menjadi 2,8.

Ketiga, berdasarkan hasil penilaian membaca puisi anak dengan pendekatan Contextual Teaching and Learning, diperoleh rata-rata nilai hasil tes dan tugas mengalami peningkatan dari pembelajaran Siklus I sebesar 70,89 pembelajaran Siklus II menjadi 75,59 dan pada pembelajaran Siklus III menjadi 79,71. Peningkatan prosentase ketuntasan belajar klasikal pada pembelajaran siklus I sebesar 41,18\%, pembelajaran Siklus II menjadi 58,82 \%, dan pada pembelajaran Siklus III mencapai 82,35\%. Dengan demikian melalui pendekatan Contextual Teaching and Learning kemampuan membaca puisi anak pada Siswa Kelas V SD Negeri 2 Nanggulan Kecamatan Cawas Kabupaten Klaten semester I tahun pelajaran 2018/2019 dapat meningkat.

\section{Referensi}

[1] BNSP, 2006. Permendiknas No. 22 Tahun 2006 TentangStandar Isi, Jakarta: BNSP

[2] Imam Syafi'i, Abdus Sukur Gliazal, 1996. Petunjuk Guru, Jakarta: Depdikbud

[3] Depdikbud, 1993. Pembelajaran Sastra Indonesia, Jakarta : Balai Pustaka

[4] Tarigan, Henry Guntur. 2008. Membaca sebagai suatu Keterampilan Berbahasa. Bandung : Angkasa

[5] Waluyo, Herman J. 2008. Teori dan Apresiasi Puisi. Jakarta : Erlangga.

[6] Syah, Djalinus. 1992.Kamus Pelajar Kata Serapan Bahasa Indonesia. Jakarta: PT Gramedia

[7] Fuad Hassan, 1988. Renungan Budaya, Jakarta: Balai Pustaka

[8] Wallace, Robert, 1987. Writing Poems, Boston: Little Brown and Company

[9] Depdiknas, 2002. Kurikulum dan Hasil Belajar Rumpun Pelajaran Berbahasa Indonesia, Jakarta: Pusat Kurikulum Balitbang 